609

\title{
Stoppage of Pneumatic Capsule in a Vertical Pipeline
}

学 田篞 哲也（九工大院） 正 富田 侑呞（九工大） 正 船津 勝也（九工大）

TAKUBO,Tetsuya, Kyushu Institute of Technology, 1-1 Sensui-cho, Tobata-ku, Kitakyushu

TOMITA Yuji, Kyushu Institute of Technology, FUNATSU Katsuya,Kyushu Institute of Technology

Key words: Stoppage, Capsule Geometry, Revolution, Rotation, Without Wheels

\section{1. 粕言}

空気桧送の一つにカプセル陯送がある. カプセル陯送は被 䜽送物をカプセルに入れ，カプセルを空気によって管路陯送 するものである. 車輖がないカプセル会送においてカプセル を輸送するのに十分な空気速度であるにもかかわらず, カプ セルが管内において停止することがあるといわれている.こ れは空気速度がカプセルを移動させるのに十分な場合におい て，カプセルの移動速度が極端に低下する現象といえる。こ の様な現象は実際に観察されているが，これまでそのメカニ ズムや発生条件を調べた研究はほとんどみられない.よって, 鈶值管内において種々の铪送条件によってカプセルの停止現 象を実駼的に钼察した。本研究では，その防止方法を検討し ようとするものである.

\section{2.実筑方法}

\section{1 実鮌}

本研究で使用した実験装置を Fig.1 に示す．吸引式空気签 送システムを用いた。㢵送管は内径 $28 \mathrm{~mm}$, 外径 $38 \mathrm{~mm}$, 長 さ $2 \mathrm{~m}$ のアクリルパイプを用いた. カプセルは挿入装置によ つて，入口で常に渝送管鉛直轴上にセットされ，フローメー ターにより設定の流量が得られた後, 発射される.八イスピ ードカメラを用いて, カプセルの自転, 公転, 鈶直軸に対す るカプセルの傾きを測定した．カプセルの自転，公転は挿入 口から $700 \mathrm{~mm}$ 1070mm の区間で測定した。鈶值軸に対する カプセルの㑯きは㨂入ロから $380 \mathrm{~mm} 480 \mathrm{~mm}$ の区間で，計測 した.

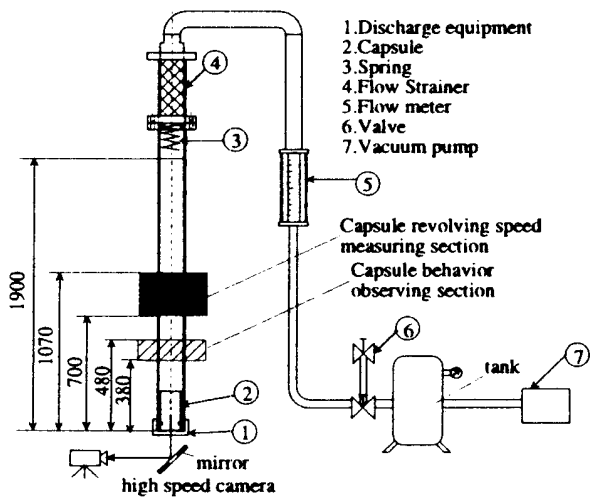

Fig.1 Experimental apparatus.

2.2 カプセルについて

実験に用いたカプセルの形状を Figs.2 4 に示す。すべて密 度 $1410 \mathrm{~kg} / \mathrm{m}^{3}$ のポリプロピレン彆で長さ $l=63.6 \mathrm{~mm}$, 直径 $\mathrm{D}=24.55 \mathrm{~mm}$ である. Fig.2 は質量 $m$ が同じ $(m=76.33 \mathrm{~g})$ 円柱状 カプセルである．鈆の鍾によって重心位置を変えその影䈉を 調べた。またカプセル表面にテープを巻いて摩擦係数を大き くし，その影響を調べる. 摩擦係数はそれぞれ $\mu=0.15$ と 0.82 である. Fig.3 は凸型カプセルでの突起の径 A を変化させそ の影敬を調ベる. Fig.4 は薬瓶型のカプセルで蓋径 B を変化 させその影響を調べる.

Table 1 Center of mass of the cylindrical capsule ( $l=c a p s u l e$ length, $\boldsymbol{l}_{c}=$ center of mass from the capsule bottom)

\begin{tabular}{|c|c|c|c|c|c|c|c|c|c|}
\hline No. & 1 & 2 & 3 & 4 & 5 & 6 & 7 & 8 & 9 \\
\hline$l_{c}(\mathrm{~mm})$ & 11.52 & 16.76 & 22.09 & 27.18 & 31.8 & 36.42 & 41.58 & 46.84 & 52.08 \\
\hline$l_{\Omega} \Omega$ & 0.18 & 0.26 & 0.35 & 0.43 & 0.50 & 0.57 & 0.65 & 0.73 & 0.82 \\
\hline
\end{tabular}
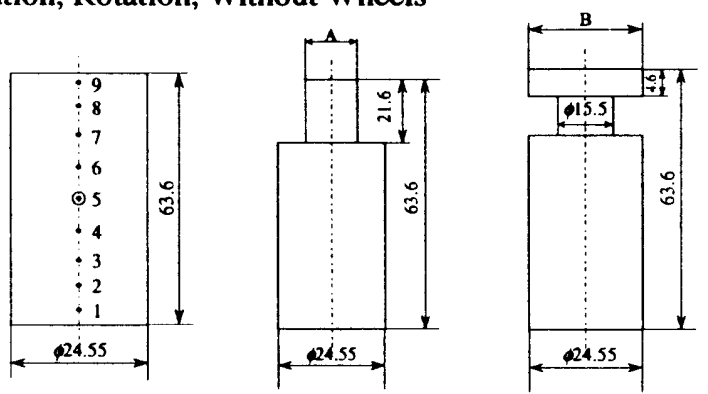

Fig.2 Cylindrical capsule. Fig.3 Capsule with Fig.4 Bottle type capsule. protuberance.

\section{3.寒路果}

\section{1 重心位国の建いによるカプセル举影}

\subsection{1 カプセルの鉛直㣙に対する㑯き}

Fig.5 に空気流速 $U=7.9 \mathrm{~m} / \mathrm{s}$ でのカプセルの鉛直轴に対する 頃斜角の RMS 值 $\sqrt{\theta^{2}}$ と 凡 の関係を示す $z$ 軸を鈶直轴とする 直角座標系で，互いに值交する鉛直断面での测定值である。 重心が低いカプセルほど鉛直軸に対する傾きが小さくなって いるのがわかる. 重心が低いものほど安定することを示して いる.

\subsection{2 カプセルの自転と公転}

Fig.6に空気流速 $U=8.17 \mathrm{~m} / \mathrm{s}$ でのカプセルの公転数 $N_{r}$, 自転 数 $N_{s}$ の関係を示す. それぞれのUで停止現象が生じるときと 生じない時があり，【几が大きくなるに従い，大きな確率で停 止現象が生じる. カプセルが停止現象を生じている時は自転 数, 公伝数共に高く, 自枟と公転は常に逆方向である. 更に 自転数と公転数の関俰から，ほほ転がりなしの条件で回転し ていることが分かる. 停止現象はカプセルが遠心力によって 管壁におしつけられることによってz方向に摩擦力が倬き， 生じるものといえる。摩擦係数を大きくするとN 全てのカプセルがほとんどの場合停止現象を生じた. 次に重 心位置に着目すると, 重心位置が低いものほど回転数が低い 値をとっている. 特に重心位置の最も低いカプセル $l \Omega=0.18$ は $\mu=0.82$ の時も停止現象を生じることはなかった。 それに対 して重心位置の高いカプセル $l \Omega=0.65$ と0.74では摩擦力が小 さい場合でも停止現象がみられた。

重心位置によるカプセルの運動の違いは前述したカプセル の傾斜角のRMS值と同様の傎向を示している. カプセルが 傾くことにより流体からの, 剪断力はカプセル表面に斜め方 向に俳くことになる．よってその剪断力がカプセルを自転さ せるモーメントになることから重心の高いものほど㑯きが大 きくなり，回轱運動が生じやすくなると考えられる.

\section{2 形状による学到の遗い}

\subsection{1 凸型カプセル}

凸型力プセルの突起の径Aを変化させ運動を調べた． Fig.7 はU $6.5 \mathrm{~m} / \mathrm{s}$ の $N$, とAVDの関係を示す. $A / D か ゙$ 小さいと質量も少 ないが, 突起径Aが小さいと停止現象を生じ, $A / D=0.6$ 付近で 一旦回転数は小さくなり停止現象が見られなくなる.しかし， $A / D=0.9$ で再び停止現象が起きている. $A / D=0.6$ と0.9において も同一流速で停止現象が起きる場合と起きない場合があった. 停止現象が起きる確率はテープを巻いて摩擦係数を大きくし た時と比較して少ない。この場合 $A / D=1.0$ では停止現象は生 じなかった. また $A / D=0.7$ と0.8でも停止現象は見られなかっ た.

Fig.8は種々のAVDにについて $N$ とUの関係を示す。やはり $A / D=0.6$ と0.9においては同一流速で停止現象が起きる場合之 
起きない場合があった．流速が大きくなるに従い，停止現象

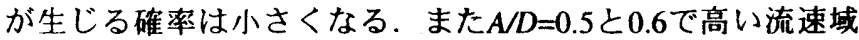
においては停止現象を生じていなかった。したがってUを大 きくすることで形状によっては停止現象を防止することがで きる. よって空気速度 $U=7.6 \mathrm{~m} / \mathrm{s}$ 付近で二つの現象がみられる のはそれがこのカプセルの運動挙動の遷移流速域であると考 えられる。

3.2 .2 薬瓶型カプセル

実際に使用されている薬瓶と同形状のカプセルを用いて蓋 径による運動の違いをみた。 B/Dと $N_{r}$ の関係をFig.9に示す. 空気速度は $U=5.9 \mathrm{~m} / \mathrm{s}$ である．盖径が小さいと停止現象がみら れない. 径が大きくなるにつれ公転数は大きくなり， $B / D=0.9$ で停止現象を生じ公転数は大きい. B/D=1すなわち力プセル 径と等しくなった時点で停止現象が生じなくなった。 Fig.10 に空気速度 $U$ と $N_{r}$ の関係を示す. 全ての流速域で $B / D=0.9$ 最 も高い公転数を示している. $B / D=1$ はほとんど公転を行って

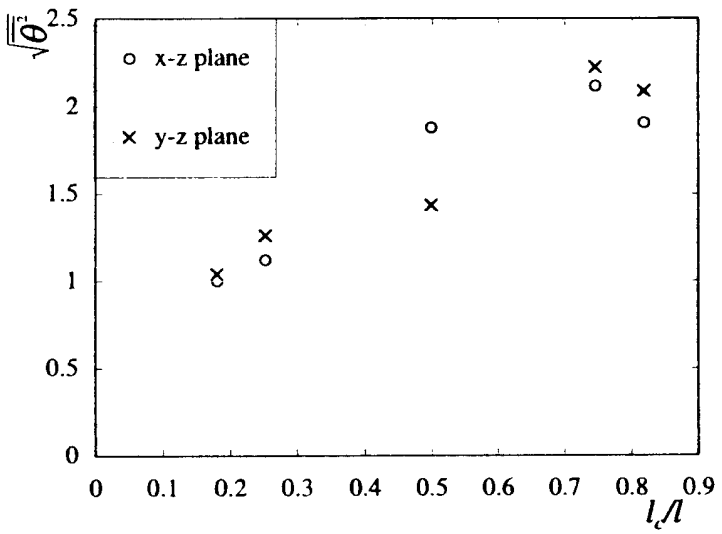

Fig.5 Effect of center of mass on capsule posture $(U=7.9 \mathrm{~m} / \mathrm{s})$.

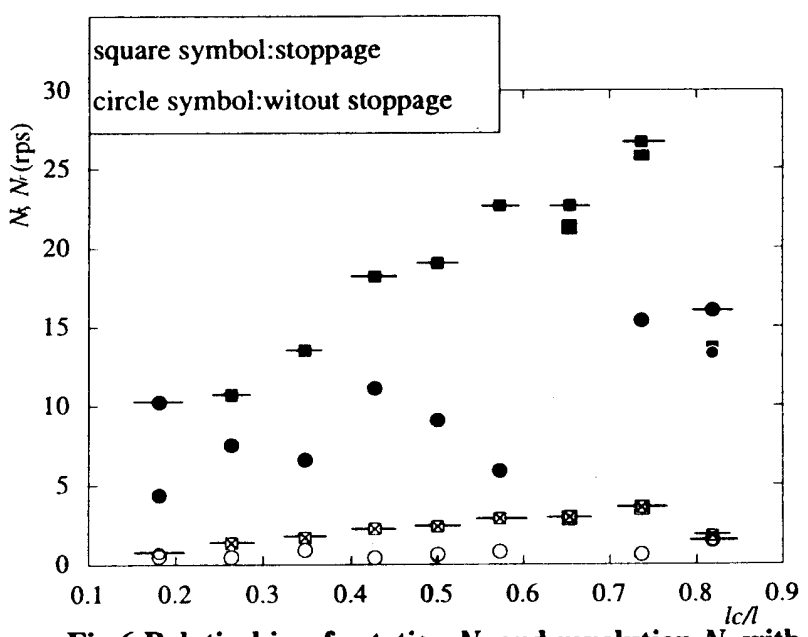

Fig.6 Relatioship of rotation $N_{s}$ and revolution $N_{r}$ with the center of mass $l \Omega$, closed symbol:revolution,open symbol:rotation,

bar: with tape $(U=8.17 \mathrm{~m} / \mathrm{s})$.

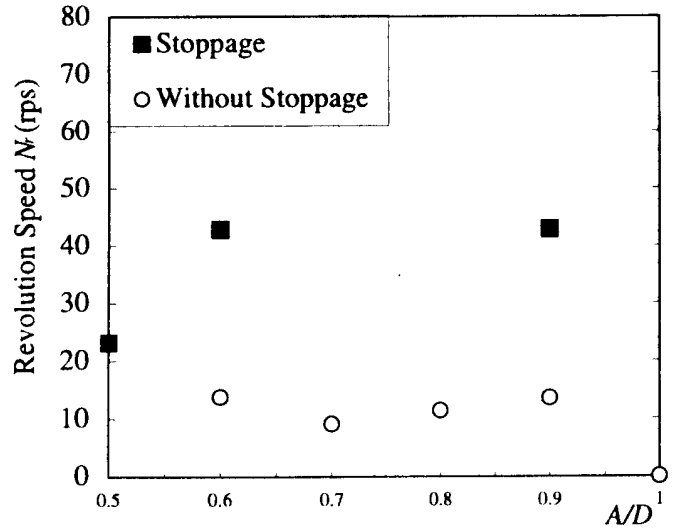

Fig.7. Relationship between $N_{r}$ and $A / D(U=6.5 \mathrm{~m} / \mathrm{s})$.
いない. また $B / D=0.98$ は流速が大きくなると停止現象を生じ ず運動が遷移している.このことからも空気流速を大きくす ることで停止現象が防止できるといえる.

\section{4.䑩部}

本研究より以下のことがわかった。

1)停止現象を生じているカプセルは激しく回転している.

2）重心位置が下のものほど鉛植轴に对する頃きはすくなく なり，その結果停止現象を生じにくい.

3) カプセル形状により停止現象が生じやすいものとそうで ないものがある.

この結果から，カプセルの停止現象の防止法や生じやすい 条件等が明らかになる.

\section{考文盛}

(1) J.P.Den Hartog 著, 谷口・藤井共訳, “機栊振動論”, コロナ社(1970).

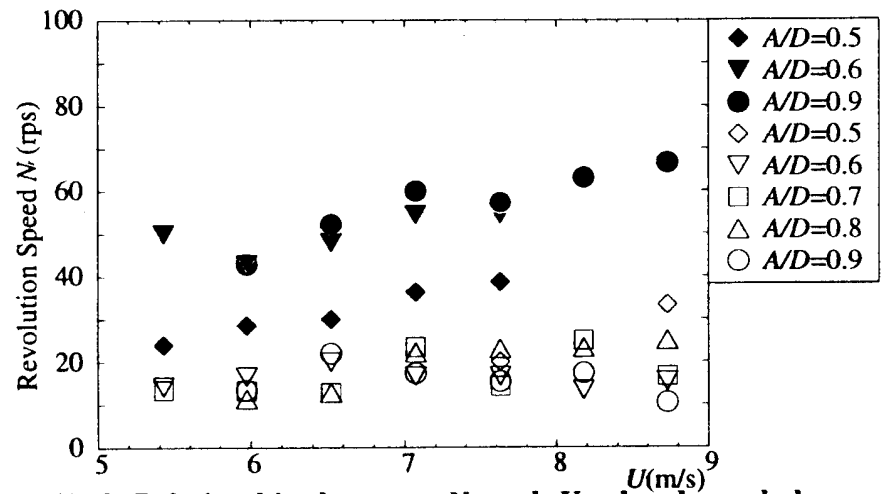

Fig.8 Relationship between $N_{r}$ and $U$, closed symbol: stoppage, open symbol: without stoppage.

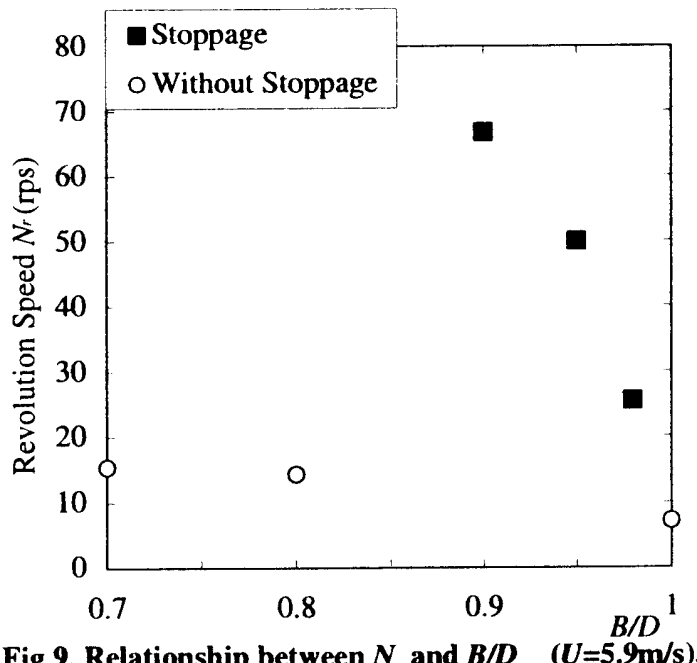

Fig.9. Relationship between $N_{r}$ and $B / D \quad(U=5.9 \mathrm{~m} / \mathrm{s})$.

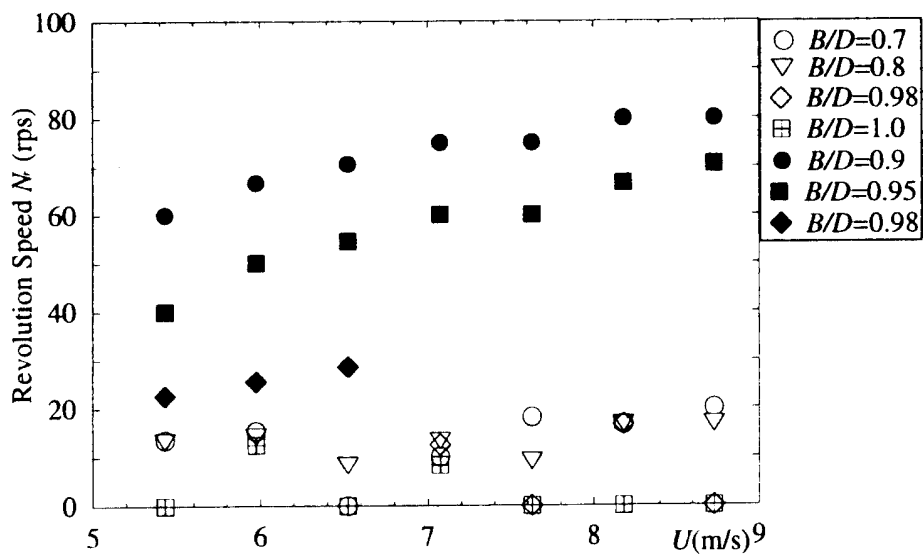

Fig.10 Relationship between $N_{r}$ and $U$,closed symbol: stoppage,open symbol: without Stoppage. 